\title{
Peningkatan Service Quality Of Employee Dengan Servant Leadership dan Self-Efficacy di Kementerian Kelautan dan Perikanan (KKP)
}

\author{
¿ OPEN ACCESS \\ Citation: Amalia Putri, S., \& Siwi Agustina, \\ T., Delita Merida, P. \& Eliyana, A. (2021). \\ Peningkatan Service Oualiy Of Emplojee. \\ Peningkatan Service Quality Of Employee \\ Dengan Servant Leadership Dan Self-Efficacy \\ di Kementerian Kelautan dan Perikanan \\ (KKP). Matra Pembaruan. 5(1), 25-38 \\ Received: January 30, 2021 \\ Accepted: March 15, 2021 \\ Published: May 31, 2021
}

(c) The Author(s)

\section{cc)(ㄱ) (2)}

This work is licensed under a Creative Commons Attribution-NonCommercialShareAlike 4.0 International License.
Keywords: Self Efficacy, Servant Leadership, Service Quality, Government Employee, Development Governance.

Kata Kunci: Efikasi Diri, Kepemimpinan Melayani, Kualitas Pelayanan, Pegawai Pemerintah, Tata Kelola Pembangunan.

\author{
Syavina Amalia Putri ${ }^{1}$, Tri Siwi Agustina ${ }^{2}$, Peggy Delita Merida ${ }^{\text {iD }}{ }^{3}$, Anis Eliyana \\ (iD) 4 \\ ${ }^{1}$ Mahasiswa Magister Sains Manajemen, Universitas Airlangga, ${ }^{2,4}$ Dosen Magister Sains Manajemen, \\ Universitas Airlangga, ${ }^{3}$ Dosen Departemen Ekonomi dan Bisnis, Universitas Katolik Widya Mandala \\ Surabaya
}

${ }^{1} \mathrm{Jl}$ Airlangga No.4-6, Airlangga, Gubeng, Kota Surabaya, 2,4JI Airlangga No.4-6, Airlangga, Gubeng, Kota Surabaya. Surabaya, ${ }^{3} \mathrm{Jl}$ Kalisari Selatan No.1, Mulyorejo, Surabaya.

\section{ఐ syavina.amalia.putri-2019@feb.unair.ac.id}

\begin{abstract}
The concept of servant leadership has been referred to as a form of leadership approach that is committed to empowering the abilities and needs of employees. Currently, the concept of leadership has attracted the attention of most researchers in terms of the increasing number of moral violations of management and workplace irregularities.. This study aims to know how the direct influence of servant leadership and self-efficacy on employee service quality and the effect of servant leadership moderation on two variables, namely self-efficacy of service quality of employees and service quality of employees. The researcher used Structural Equation Modeling (SEM) methodologically with AMOSGrapchics. There were two studies in this research. The data in the first and second studies was obtained from the distribution of online questionnaires to the State Civil Service (SCS) of the Ministry of Marine Affairs and Fisheries (KKP). A total of 222 Civil Servants were available. The study resulted in several tests related to (1) servant leadership has a significant effect on the service quality of Civil Servants employees at KKP, (2) self-efficacy has a significant effect on employee service quality, and (3) servant leadership can significantly moderate between self-efficacy and service quality employees of Civil Servants at the KKP.
\end{abstract}

\begin{abstract}
Abstrak: Konsep mengenai servant leadership telah disebut sebagai salah satu bentuk pendekatan kepemimpinan yang berkomitmen untuk memberdayakan kemampuan serta kebutuhan karyawan. Saat ini konsep kepemimpinan tersebut telah menyita perhatian sebagian besar peneliti dalam hal semakin banyaknya pelanggaran moral dan penyimpangan manajemen di tempat kerja. Penelitian mengenai hal ini bertujuan untuk mengetahui tentang bagaimana pengaruh langsung servant leadership dan selfefficacy terhadap service quality karyawan serta efek moderasi servant leadership terhadap dua variabel, yaitu self-efficacy of service quality of employee dan service quality of employee. Peneliti menggunakan model analisis Structural Equation Modeling (SEM) secara metodologis dengan alat uji analisis statistik AMOSGrapchics. Ada dua studi dalam penelitian ini. Data pada studi pertama dan kedua diperoleh dari pendistribusian kuesioner online pada Aparatur Sipil Negeara (ASN) Kementerian Kelautan dan Perikanan (KKP). Responden yang valid tersedia sebanyak 222 ASN dalam penelitian ini. Penelitian menghasilkan beberapa pengujian yang berkaitan (1) servant leadership berpengaruh signifikan terhadap service quality karyawan ASN di $\mathrm{KKP}$, (2) self-efficacy berpengaruh signifikan terhadap service quality karyawan, dan (3) servant leadership dapat memoderasi secara signifikan antara self-efficacy dengan service quality pegawai ASN di KKP.
\end{abstract}




\section{Pendahuluan}

Dalam sebuah organisasi publik, konsep mengenai servant leadership telah disebut sebagai salah satu bentuk pendekatan kepemimpinan yang berkomitmen untuk memberdayakan kemampuan serta kebutuhan karyawan. Saat ini konsep kepemimpinan tersebut telah menyita perhatian sebagian besar peneliti dalam hal semakin banyaknya pelanggaran moral dan penyimpangan manajemen di tempat kerja. Servant leadership adalah pendekatan holistik yang melibatkan karyawan dalam berbagai dimensi (misalnya, relasional, etis, emosional, dan spiritual), sehingga mereka diberdayakan untuk tumbuh dan berkembang sesuai dengan kemampuannya (Qiu, Dooley, and Xie 2020). Dalam penerapannya, kesejahteraan dan perkembangan individu sebuah organisasi yang diprioritaskan akan fokus pada kesungguhan dalam melayani dan memastikan bahwa individu tersebut akan dapat tumbuh serta mencapai kesejahteraan pribadi mereka (Rachmawati and Lantu 2014).

Beberapa penelitian yang telah dipublikasikan dengan topik yang serupa, yakni servant leadership telah mengidentifikasi pengaruh servant leadership sebagai pendorong efektivitas sebuah organisasi. Hasil penelitian menunjukkan bahwa pengaruh servant leadership pada seorang pemimpin organisasi berpengaruh positif terhadap karyawannya dan mampu memberikan motivasi prososial terhadap kinerja karyawan (Stollberger et al. 2019). Begitu juga dengan pengaruh servant leadership pada perbedaan yang dirasakan dalam kualitas hubungan antara atasan dengan bawahan dalam sebuah organisasi yang secara langsung akan berdampak pada kinerja tugas tim dan Organizational Citizenship Behaviour (OCB) (Yin, Han, and Perron 2020). Servant leadership secara signifikan memprediksi, jika perbedaan yang dirasakan dalam hubungan antara atasan dengan bawahan rendah, maka akan memperkuat kekompakan dalam sebuah tim organisasi (Chiniara and Bentein 2018). Berry (2015) berpendapat bahwa servant leadership adalah mesin penggerak bagi organisasi menuju keunggulan layanan. Selain penting dalam hal keunggulan layanan, servant ledership juga memberikan pengaruh secara signifikan terhadap budaya organisasi, komitmen organisasi, OCB dan kinerja individu dalam organisasi (Harwiki 2016).

Self-efficacy menjadi salah satu dimensi dari kerangka model psikologis ketika diterapkan dalam sebuah organisasi (Qiu, Dooley, and Xie 2020). Pada dasarnya, self-efficacy adalah keyakinan diri pada kapasitas seseorang untuk mengerahkan motivasi sumber daya kognitif dan tindakan yang diperlukan untuk tuntutan kerja yang situasional (Brender-Ilan and Sheaffer 2019). Oleh karena self-efficacy berkaitan dengan kepercayaan diri pada tiap jenis karakter individu, maka dalam faktor selfefficacy sangat relevan dengan psikologis para Aparatur Sipil Negara (ASN).

Dalam memberikan pelayanan kepada masyarakat yang sesuai dengan standar yang ditetapkan, dibutuhkan self-efficacy pada setiap ASN untuk mampu membangun unit pelayanan yang berintegritas dan memberikan pelayanan dengan kualitas prima. Hal tersebut adalah bagian dari inovasi kerja para ASN pada sektor publik. Inovasi dalam sektor publik dapat dikaitkan dengan peningkatan dalam proses organisasi dan implementasi self-efficacy mengenai produk, prosedur, layanan, dan kebijakan baru (Pete Devon et al. 2019).

Hal ini didukung dengan penelitian terkait hubungan positif antara self-efficacy dengan stres kerja, sehingga perlu adanya upaya untuk meningkatkan self-efficacy pada diri individu karyawan untuk mengurangi intensitas stres kerja yang dirasakan (Yin, Han, and Perron 2020). Berdasarkan beberapa penelitian terdahulu yang melakukan penelitian terkait servant leadership dan self-efficacy sebagian dilakukan pengujian secara bersamaan sebagai bentuk interaksi antar variabel yang mempengaruhi kinerja karyawan. Selain itu, penelitian sebelumnya hanya meneliti organisasi yang bergerak di perusahaan bidang pariwisata, seperti restoran, hotel dan di perusahaan swasta. Sehingga, pembaruan dalam penelitian ini adalah dilakukan pada sektor organisasi publik, yakni Kementerian Kelautan dan Perikanan (KKP) di Indonesia yang memiliki jangkauan lebih luas untuk dapat dilakukan sebuah penelitian serta adanya pengujian servant leadership yang memoderasi hubungan antara self-efficacy of service quality of employee terhadap service quality of employee. 
Sektor publik memiliki peranan penting dalam masyarakat (Demircioglu and Audretsch 2017). Prioritas sektor publik dalam hal pelayanan selalu mengutamakan kepuasan warga, yakni mengenai keputusan dalam manajemen publik yang masih didasarkan pada formasi yang tidak konsisten, sehingga menyebabkan ketidakefisienan (Pete Devon et al. 2019). Pernyataan tersebut sesuai dengan kondisi kinerja ASN KKP di Indonesia yang dikutip dari Siaran Pers Jakarta pada (2/5/2019) mengenai Diskusi Peningkatan Kualitas Pelayanan Publik Standar PTSP (Pelayanan Terpada Satu Pintu) dengan stakeholders, bahwa pemerintah harus mampu melakukan perbaikan secara terus-menerus yang meliputi standar pelayanan, maklumat pelayanan, sarana dan prasarana pelayanan, budaya pelayanan prima, dan inovasi pelayanan sesuai dengan peraturan perundang-undangan yang berlaku. Pemimpin organisasi publik ini, yakni Sekretaris Jenderal KKP menginginkan agar para ASN dapat memegang teguh prinsip pelayanan publik yang harus dimengerti dan diikuti. Sehingga, berdasarkan pemaparan tersebut sesuai dengan pengujian variabel mengenai servant leadership dan self-efficacy yang menuntut para ASN untuk dapat optimal dalam memberikan pelayanan publik.

Kondisi kerja yang demikian menjadi penting untuk dilakukan pengujian tentang hubungan satu sama lain antar servant leadership dengan self-efficacy dan moderasi dari servant leadership yang mempengaruhi service quality para ASN. Hal ini selain disebabkan oleh kondisi dan tuntutan kerja dari pemimpin yang demikian, banyak peneliti yang belum menyelidiki tentang bagaimana kepemimpinan organisasi sektor publik dalam memberikan pengaruh pada kualitas pelayanan yang diberikan oleh ASN kepada masyarakat atas keluhan yang dirasakan, serta bagaimana self-efficacy para ASN mempengaruhi kualitas pelayanan yang diberikan kepada masyarakat. Hal yang melatarbelakangi peneliti melakukan penyelidikan atas variabel tersebut adalah adanya berbagai pengaduan keluhan yang disampaikan melalui media massa dan perorangan mengenai pelayanan publik KKP di Indonesia, sehingga menimbulkan kesan yang kurang baik terhadap Aparatur Pemerintah (Survei Kepuasan Masyarakat terhadap Pelayanan Publik ST. PSDKP BIAK Semester I, 2019). Pengaduan tersebut di antaranya adalah pengerjaan dan pengaduan kerja yang berbelit-belit, tidak terkelola, terbatasnya fasilitas sarana dan prasarana pelayanan, sehingga tidak menjamin adanya kepastian (hukum, waktu, dan biaya). Hal tersebut sesuai dengan konsep penelitian ini, bahwa adanya keyakinan atas kemampuan diri sendiri sangat mendukung upaya peningkatan kualitas pelayanan ASN yang diberikan kepada masyarakat atas keluhan yang diterima oleh pihak organisasi sektor publik KKP.

Seorang individu yang memiliki self-efficacy dengan tingkat tinggi akan lebih percaya diri dalam menghadapi tantangan pekerjaan dan menangani masalah (Qiu, Dooley, and Xie 2020). Namun, dalam melayani masyarakat, para ASN seringkali dipengaruhi oleh faktor psikologis, yang meliputi stres kerja, kurangnya keyakinan diri akan kompetensi yang dimiliki, serta tekanan mental. Kemungkinan penyebab atas tekanan mental yang dirasakan oleh individu dapat berasal dari faktor internal maupun eksternal (Morales and Pérez-Mármol 2019). Sehingga, oleh karena penyebab tersebut para ASN dalam sebuah organisasi publik kurang dapat mengoptimalkan kualitas pelayanannya terhadap masyarakat. Hal yang demikian penting bagi ASN yang bekerja di sektor publik untuk lebih percaya diri dengan kompetensinya dan menangani kompleksitas pekerjaan untuk terus berinovasi dalam memberikan pelayanan yang berkualitas tinggi. Dalam organisasi sektor publik, intensitas pengaduan atas keluhan, kritik dan saran dari masyarakat sangat tinggi (Niu 2010). Hal tersebut dibutuhkan pemberian perhatian khusus pada faktor Sumber Daya Manusia (SDM) yang memiliki tingkat komunikasi tinggi dengan masyarakat. Sehingga, self efficacy yang tinggi berpengaruh pada bagaimana kualitas pelayanan yang diberikan.

Dalam penelitian lain terkait pengaruh langsung antara servant leadership terhadap service quality dapat memberikan keunggulan yang kompetitif. Luu (2020) membenarkan bahwa dari hasil analisis data menunjukkan adanya hubungan positif antara servant leadership dan pengaruh Organizational Citizenship Behaviour (OCB) terhadap kinerja pemulihan layanan dalam konteks Business to Business (B2B). Hubungan positif antara servant leadership dan pengaruhnya terhadap manajemen 
Sumber Daya Manusia (SDM), dibuktikan pada penelitian lain yang mengemukakan bahwa penerapan servant leadership mampu dalam memimpin dan memberikan wawasan kepada para pekerja bisnis, baik dalam konteks Indonesia maupun negara asing dalam sebuah perusahaan (Andre and Lantu 2015). Sehingga, berdasarkan penelitian tersebut peneliti mengusulkan hipotesis antara pengaruh langsung servant leadership terhadap service quality of employee.

Hipotesis 1. Servant leadership berpengaruh positif terhadap service quality of employee.

Dalam bentuk-bentuk ketidaksesuaian yang lain, pengaruh self-efficacy yang dianggap tidak berpengaruh positif akan lebih kecil kemungkinannya menghasilkan kinerja yang baik (service quality of employee). Penelitian di bidang pendidikan menunjukkan bahwa self-efficacy memberikan pengaruh positif terhadap kepuasan kerja (Ismayilova and Klassen 2019). Dalam penelitian lain di bidang keperawatan, Kurniawan (2019) menunjukkan hasil analisis data bahwa dengan adanya kehadiran dari self-efficacy yang tinggi akan menjadi suatu predictor khusus pada faktor kepuasan kerja dan kualitas kinerja perawat, baik untuk perawat baru maupun lama. Di bidang yang sama, self-efficacy memiliki hubungan positif dengan emotional intelligent (EI) pada staf kesehatan yang berpengaruh pada kualitas kinerja dan tidak ditemukan perbedaan yang signifikan antara bidang pekerjaan operasional dengan administrasi (Tabatabaei et al. 2013). Hal ini menunjukkan bahwa semakin tinggi self-efficacy yang dimiliki oleh individu akan memberikan hasil kinerja yang baik. Oleh karena itu, peneliti mengharapkan self-efficacy PNS dapat memiliki hubungan positif terhadap service quality, sehingga peneliti mengusulkan hipotesis sebagai berikut:

Hipotesis 2. Self efficacy of service quality berpengaruh positif terhadap service quality of employee.

Individu yang memiliki self-efficacy cenderung akan terlibat dalam pengaturan diri yang lebih baik (Qiu, Dooley, and Xie 2020). Namun, tinggi atau rendahnya self-efficacy didasarkan pada beberapa faktor lain yang berpengaruh pada kinerja, di antaranya adalah kepemimpinan yang dirasakan oleh karyawan (Wang, Xu, and Liu 2018). Salah satu yang menjadi permasalahan besar dalam sebuah organisasi sektor publik adalah ketika ASN memiliki kemampuan dalam potensi yang ada dalam dirinya tinggi, namun gaya kepemimpinan yang dirasakan tidak sesuai atau bisa dikatakan rendah, maka yang terjadi adalah kinerja yang dihasilkan akan memburuk. Tentu dengan adanya ilustrasi tersebut, dapat menurunkan keinginan individu dalam memberikan kinerja terbaiknya.

Servant leadership dalam ilustrasi tersebut akan memberikan sebuah bentuk penyelesaian berupa pemulihan emosional dan peduli dengan kesejahteraan karyawan (Qiu, Dooley, and Xie 2020). Dalam penelitian lain, ditemukan hasil analisis data antara pengaruh ketidakmampuan frontline employee's (FLE's) terhadap pelangan dengan dimoderasi oleh supervisor's leadership menunjukkan adanya hubungan positif (Boukis et al. 2020). Hal ini disebabkan oleh tanggapan dari FLE's terhadap pelanggan sangat bergantung pada bagaimana gaya kepemimpinan yang didapatkan. Oleh karena itu, peneliti mengusulkan hipotesis sebagai berikut:

Hipotesis 3. Servant leadership memoderasi hubungan antara self efficacy of service quality of employee dan service quality of employee. Sehingga, hubungan positif antara self-efficacy of service quality of employee dan service quality of employee paling menonjol ketika tingkat servant leadership ASN KKP lebih rendah daripada yang lebih tinggi.

Tujuan penulisan penelitian ini adalah menyajikan dua pemahaman secara mendalam tentang bagaimana pengaruh langsung servant leadership dan self-efficacy of service quality of employee terhadap service quality of employee serta efek moderasi servant leadership terhadap self-efficacy of service quality of employee dan service quality of employee yang digambarkan dengan dua studi. Jika pada penelitian sebelumnya telah dilakukan pengujian mengenai konsep kepemimpinan yang sama, yakni servant leadership dengan objek penelitian karyawan di industri perhotelan (Qiu, Dooley, and Xie 2020), maka penelitian saat ini akan menggunakan Aparatur Sipil Negara (ASN) Kementerian Kelautan dan Perikanan (KKP) KKP sebagai objek penelitian.

Selain itu, pembaruan lainnya yang dilakukan pada penelitian saat ini adalah 
Gambar 1. Kerangka Konseptual Studi 1 penggunaan variabel moderasi yang berbeda. Pada penelitian sebelumnya, peneliti menggunakan self-efficacy sebagai moderator pada pengaruh servant leadership dan service quality (Qiu, Dooley, and Xie 2020). Sedangkan, penelitian saat ini menggunakan servant leadership sebagai moderator pada pengaruh self-efficacy of service quality of employee dan service quality of employee untuk mendapatkan deskripsi efek interaksi yang lebih menyeluruh.

\section{Metode}

Penelitian ini merupakan penelitian kuantitatif yang dilakukan dengan uji analisis statistik pada pengaruh langsung servant leadership dan self efficacy of service quality terhadap service quality of employee sebagai studi pertama dan pengaruh servant leadership sebagai moderasi pada pengaruh self-efficacy of service quality terhadap service quality of employee sebagai studi kedua. Kedua studi ini dilakukan pada awal tahun 2020, di mana pelayanan ASN di Kementerian Kelautan dan Perikanan (KKP) saat itu sedang berada dalam tahap adaptasi terhadap regulasi baru. Regulasi tersebut dibuat sebagai bentuk tanggapan atas maraknya keluhan yang disampaikan masyarakat dan termuat dalam Laporan Survei Kepuasan Masyarakat terhadap Pelayanan Publik ST. PSDKP BIAK Semester I, 2019. Sehingga, dengan dilakukannya penelitian pada waktu tersebut, peneliti memperoleh informasi tentang gambaran objek penelitian dengan kesesuaian model konseptual yang diajukan.

\section{II.a. Studi 1}

Studi 1 bertujuan untuk menguji model konseptual yang peneliti usulkan. Secara khusus, peneliti mencoba untuk menguji pengaruh langsung servant leadership terhadap service quality of employee serta pengaruh langsung dari self efficacy terhadap service quality of employee. Peneliti menggeneralisasikan konsep penelitian sebagai berikut:

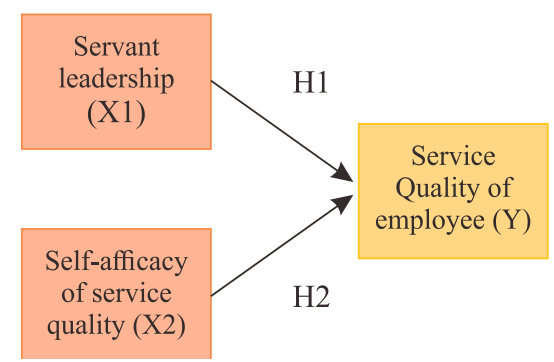

Teknik analisis yang digunakan pada kedua studi ini adalah Structural Equation Modelling (SEM). SEM dinyatakan bagus dalam menangani pengukuran dan model jalur (path analysis), tetapi tidak disarankan pada struktur data yang berkerumun (Sun and Xia 2018). Berdasarkan manfaat analisis SEM, peneliti mengusulkan pendekatan ini agar dapat diterapkan untuk memeriksa pengaruh langsung antar variabel dan regresi yang dimoderasi.

\section{a. Sampel dan Prosedur}

Sampel dari penelitian ini diperoleh dari ASN Kementerian Kelautan dan Perikanan (KKP) dari seluruh divisi. Sebelum melakukan survei, peneliti menghubungi salah satu kepala bagian divisi di Kementerian Kelautan dan Perikanan (KKP) untuk meminta izin melakukan survei. Di dalam surat pengantar penelitian, peneliti akan menjelaskan tujuan dari penelitian ini, memastikan kerahasiaan tanggapan, dan mempresentasikan instruksi terperinci dalam kuesioner tentang bagaimana menyelesaikan pertanyaanpertanyaan yang diajukan oleh peneliti. Indikator pengaruh langsung servant leadership dan self efficacy of service quality terhadap service quality of employee dimasukkan ke dalam studi pertama. Kemudian, kepala pada setiap divisi akan membantu peneliti untuk mendistribusikan kuesioner survei pada sekitar 222 ASN di Kementerian Kelautan dan Perikanan (KKP). Para peserta (ASN) yang mengisi kuesioner memiliki syarat di antaranya, berstatus Pegawai Negeri Sipil (PNS) aktif dan berasal dari WNI. 


\section{b. Pengukuran}

Dalam pengukuran penelitian studi 1, semua skala pengukuran diajukan dan diadopsi dari literatur. Semua item menggunakan skala Likert lima poin yang sama, yaitu format skala (1 sangat tidak setuju, 2 tidak setuju, 3 netral, 4 setuju, 5 sangat setuju).

1. Servant Leadership

Peneliti menilai servant leadership dengan menggunakan kuesioner yang diadopsi SLAI (Servant Leadership Assesment Instrument) oleh M. Bocarnea (Personal communication, July 20, 2006) yang digunakan oleh Jacobs, G.A (Jacobs 2006). Terdiri dari 9 item sebagai berikut, beberapa diantaranya adalah : 1) ketika seseorang mengkritik saya, rasanya seperti cercaan kepada saya juga, 2) Ketika saya berbicara tentang atasan saya, saya biasanya menggunakan istilah "kita", daripada menggunakan istilah "dia/ mereka", dan 3) Keberhasilan atasan saya adalah keberhasilan saya juga.

2. A Cronbach untuk Skala Self-Efficacy adalah 0,93

Pengukuran self-efficacy menggunakan skala milik Ralf Schwarzer et al., (2002) dari Universitas Freie, Berlin (Sataloff, Johns, and Kost, n.d.). Skala yang disajikan terdiri dari 10 item. Skala self-efficacy yang disusun peneliti berdasarkan aspek dari Bandura (1997) yang dituangkan dalam skala General Self-Efficacy (GSE) meliputi tiga aspek dimensi yaitu magnitude (tingkatan), strength (kekuatan), dan generality (generalitas). Selain itu menurut Ralf Schwarzer et al., (1996) koefisien reliabilitas skala milik Ralf Schwarzer antara 0,75 sampai 0,90 sehingga dapat dikatakan reliabel dan juga dapat dibuktikan. Skala self-efficacy ini disusun dengan model skala Likert yang telah dimodifikasi menjadi 5 alternatif jawaban. Pernyataan jawaban yang diberikan dengan ketentuan yaitu : sangat sesuai $(S S)=5$, sesuai $(S)=4$, cukup sesuai $(C S)=3$, tidak sesuai $(\mathrm{TS})=2$, sangat tidak sesuai $(\mathrm{STS})=1$. Contoh item pertanyaan di antaranya "saya merasa sudah berpengalaman dalam pekerjaan saya" dan "menurut saya, tidak ada hambatan bekerja yang saya alami di perusahaan ini".

3. Service Quality of Employee

Service quality of employee merupakan bagian dari harapan yang diinginkan oleh ASN. Hal ini mengacu pada konsep service quality yang diungkapkan oleh Parasuraman (1985) dalam penelitian yang menganggap service quality sebagai perbedaan antara harapan employee dan jenis layanan yang diterima oleh masyarakat (Dhar 2015).

Skala 5 indikator digeneralisasi oleh SEVQUAL instrumen dari Parasuraman (1988) digunakan untuk mengukur service quality of employee. Beberapa item berdasarkan dimensi yang digunakan diantaranya adalah bukti fisik (tangibles), keandalan (reliability), daya tanggap (responsiveness), jaminan (assurance), dan empati (emphathy) dengan beberapa pernyataan seperti (1) "Saya sebagai Pegawai Negeri Sipil (PNS) dapat diandalkan dalam menangani masalah jasa masyarakat" dan "kemampuan saya sebagai Pegawai Negeri Sipil (PNS) dapat dipercaya". Koefisien alpha untuk skala ini adalah 0,90 .

4. Variabel Kontrol

Peneliti mengontrol jenis kelamin, usia, tingkat pendidikan, dan masa kerja di Kementerian Kelautan dan Perikanan. Studi sebelumnya menunjukkan bahwa demografis ini mempengaruhi service quality of employe (Koyuncu et al. 2014). Tujuan penggunaan variabel kontrol adalah sebagai pembanding melalui penelitian eksperimental.

\section{c. Pemeriksaan Asumsi Statistik, Validitas, dan Metode Umum Bias}

Setelah mengumpulkan data, peneliti memeriksa asumsi statistik termasuk normalitas, linieritas, dan multikolineritas. Pengujian pertama, pada nilai-nilai kemiringan dan kurtosis berada diantara -1,96 sampai dengan 1,96 $(-1,96<\mathrm{CR}<$ 1,96), maka menunjukkan data terdistribusi secara normal. Kedua, dapat diketahui melalui determinan matriks kovarian untuk mengetahui multikolinearitas. Setiap dua variabel menghasilkan bentuk oval sebar plot yang artinya data linear. Terakhir, inflasi varian skor faktor (VIF) tidak melebihi 5,00 yang menunjukkan probabilitas rendah pada multikolinearitas. 
Tabel 1. Indeks Kesesuaian Model

Cronbach alpha untuk tiga skala besar di atas berkisar antara 0,76 hingga 0,96 . Untuk melakukan pengujian pada model pengukuran peneliti menggunakan Confirmatory Factor Analysis (CFA). Hasilnya menunjukkan sebuah model fit yang dapat diterima (disajikan dalam Tabel 1): X2 (diharapkan kecil) <X2 dengan df 231 adalah sebesar 267,451, Significance Probability $(>0,05)$ 0,236, RMSEA $(<0,008)$ 0,115, GFI $(>0,90)$ 0,960, AGFI $(>0,90)$ 0,889, CMIN/DF (<2 atau 3) 1,904, TLI $(>0,90) 0,993$, dan CFI $(>0,90) 0,943$. Dari delapan kriteria yang digunakan untuk menilai layak atau tidak suatu model tersebut, terdapat dua kriteria yang dinyatakan marginal dan enam kriteria lainnya dinyatakan memenuhi skor Cut of Value. Oleh karena itu, langkah-langkah yang digunakan dalam penelitian ini memiliki reliabilitas dan konstruk validitas.

\begin{tabular}{llll}
$\begin{array}{l}\text { Kriteria } \\
\text { Chisquare }\end{array}$ & $\begin{array}{l}\text { Nilai Cutt off } \\
\text { Diharapkan kecil }\left(<X^{2}\right. \\
\text { dengan df } 231 \text { adalah }\end{array}$ & Hasil Perhitungan & Keterangan \\
sebesar 267,451) & & Baik \\
\hline Sig. & $>0,05$ & 0,236 & Baik \\
\hline RMSEA & $\leq 0,008$ & 0,115 & Marginal \\
\hline GFI & $\geq 0,90$ & 0,960 & Baik \\
\hline AGFI & $\geq 0,90$ & 0,889 & Marginal \\
Kriteria & Nilai Cutt off & Hasil Perhitungan & Keterangan \\
CMIN/DF & $\leq 2$ atau 3 & 1,904 & Baik \\
\hline TLI & $\geq 0,90$ & 0,993 & Baik \\
\hline CFI & $\geq 0,90$ & 0,943 & Baik \\
\hline
\end{tabular}

Sumber: Data Diolah Penulis

\section{d. Analisis dan Hasil}

Deviasi standar dan interkorelasi dari variabel-variabel pada studi 1 telah disajikan pada Tabel 2. Seperti yang diharapkan oleh peneliti, bahwa servant leadership berkorelasi positif terhadap service quality of employee dengan koefisien korelasi 0,374 $(p<0,01)$ dan self efficacy dengan koefisien korelasi 0,453 ( $p<0,01)$.

Gambar 2 . Hasil Structural Equation Modelling

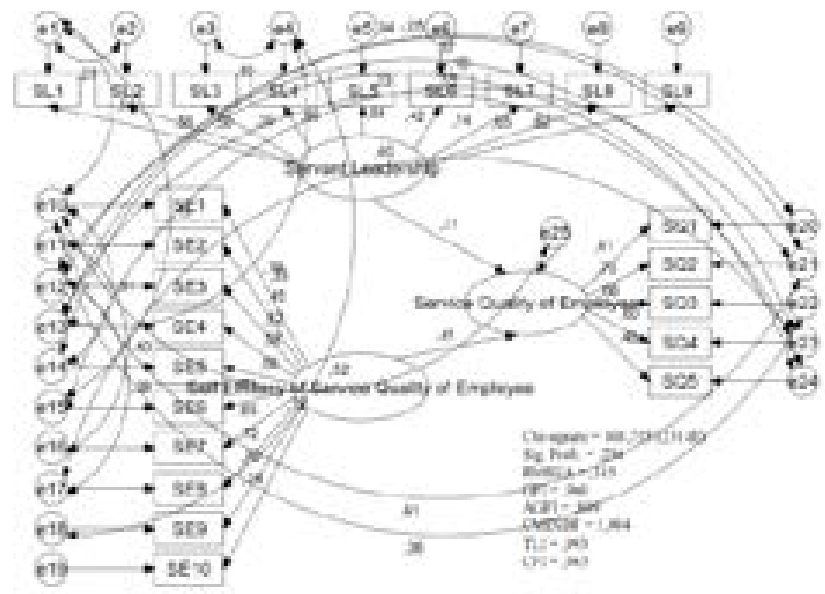

Sumber: Data Diolah Penulis

Maka, hal tersebut dapat diprediksikan bahwa servant leadership dan self efficacy cukup berkorelasi satu sama lain. Untuk menguji kausalitas hipotesis yang dikembangkan dari model penelitian tersebut, secara rinci disajikan dalam Tabel 2 sebagai berikut: 
Tabel 2. Hasil Pengujian Kausalitas

Tabel 3. Hasil Pengujian Regres

\begin{tabular}{|c|c|c|c|c|}
\hline Variabel & Koefisien Jalur & CR $\mathrm{Pr}$ & abiilitas & Keterangan \\
\hline $\mathrm{X} 1$ & $\rightarrow \quad Y \quad 0,453$ & 5,257 & 0,000 & Signifikan \\
\hline$\times 2$ & $\rightarrow \quad \mathrm{Y} \quad 0374$ & 4,216 & 0,000 & Signifikan \\
\hline
\end{tabular}

Sumber: Data Diolah Penulis

Tabel 2 adalah model dasar yang menunjukkan bahwa peneliti hanya memasukkan servant leadership dan self efficacy ke model dasar. Model $1\left(X_{1}\right)$ dan model $2\left(X_{2}\right)$ menghasilkan pengujian yang signifikan, dengan $p$ value yang lebih kecil dari $<0,05$.

Berdasarkan hasil pengujian koefisien jalur pada Tabel 2, diperoleh persamaan regresi sebagai berikut :

$Y=0,453 X_{1}+0,374 X_{2}$

$M=0,374 X_{2}$

\section{e. Tes Hipotesi}

Peneliti menghitung dua nilai pengujian efek langsung variabel $X_{1}$ dan $X_{2}$ terhadap $Y$ dan masing-masing berdasarkan tingkat signifikansi. Tabel 3 menunjukkan rangkuman hasil pengujian regresi untuk hubungan antara servant leadership, self efficacy, dan service quality of employee.

\begin{tabular}{ll} 
Hasil Pengujian Regresi & Keterangan \\
Self effficacy berpengaruh signifikan terhadap service quality of employee & Diterima \\
\hline Servant leadership berpengaruh signifikan terhadap service quality of employee & Diterima \\
\hline
\end{tabular}

Sumber: Data Diolah Penulis

Hipotesis 1 mengemukakan bahwa hubungan langsung antara servant leadership berpengaruh positif dan signifikan terhadap service quality of employee ASN di KKP. Hasil dari penelitian ini menunjukkan bahwa servant leadership berpengaruh terhadap service quality of employee ASN di KKP. Hal ini terlihat dari koefisien jalur positif sebesar 0,374 dengan CR sebesar 4,216 dan diperoleh signifikasi (p) 0,000<0,05, maka Ho ditolak dan Ha diterima, yang mengartikan bahwa servant leadership berpengaruh signifikan terhadap service quality of employee ASN di KKP. Dengan demikian, hipotesis 1 pada penelitian ini dapat diterima.

Hipotesis 2 mengemukakan bahwa self efficacy of service quality berpengaruh positif dan signifikan terhadap service quality of employee. Hasil dari penelitian ini menunjukkan bahwa self efficacy berpengaruh terhadap service quality of employee ASN di KKP. Hal ini terlihat dari koefisien jalur positif sebesar 0,453 dengan CR sebesar 5,257 dan diperoleh signifikasi (p) 0,000 < 0,05, maka Ho ditolak dan Ha diterima, yang mengartikan bahwa self efficacy berpengaruh signifikan terhadap service quality of employee di KKP. Dengan demikian, hipotesis 2 pada penelitian ini dapat diterima.

\section{2) Studi 2}

Studi 2 bertujuan untuk memperluas model dan hasil dari studi 1. Pada studi 2, data yang digunakan adalah data yang dikumpulkan pada studi 1 dari ASN Kementerian Kelautan dan Perikanan (KKP). Sampel ASN KKP digunakan untuk menguji model konseptual yang diusulkan pada studi 2. Tujuan penelitian ini juga untuk menguji pengaruh servant leadership sebagai moderasi pada self-efficacy of service quality terhadap service quality of employee. 
Gambar 3 . Kerangka Konseptual Studi 2

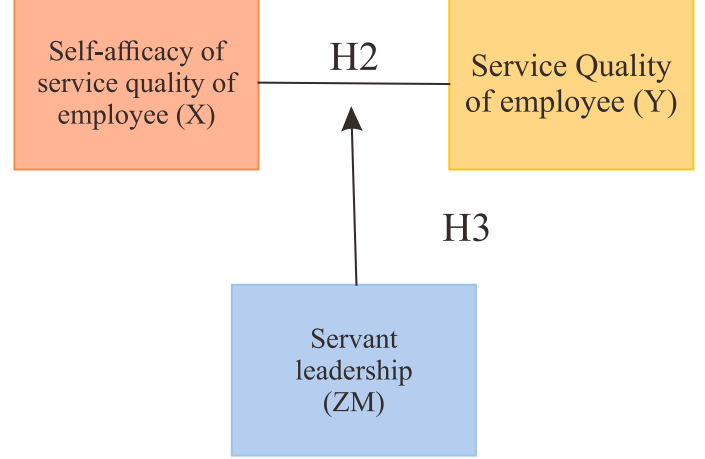

\section{a. Sampel dan Prosedur Tes Hipotesi}

Penelitian studi 2 ini dilakukan setelah pengumpulan sampel studi 1 selesai. Studi 2 dilakukan untuk mengetahui pengaruh servant leadership sebagai moderasi pada self-efficacy terhadap service quality of employee. Setelah melakukan penyebaran kuesioner melalui Google Form, peneliti menjangkau sebanyak 222 pekerja ASN dari berbagai unit/divisi kerja dan jenis jabatan di KKP. Sampel tersebut terdiri dari lakilaki 62\%, 54\% ASN di KKP berusia sekitar 31-40 tahun dari sampel, pendidikan para ASN didominasi oleh lulusan S1 sebanyak 43\%, dan sisa lainnya terdiri dari lulusan Diploma dan Magister, status perkawinan ASN sebanyak 83\% didominasi oleh pekerja yang sudah menikah, masa kerja ASN sebanyak $76 \%$ didominasi selama $>8$ tahun bekerja di KKP, dan jenis jabatan yang paling banyak di KKP adalah jabatan struktural sebanyak 68\%.

\section{b. Pengukuran}

Semua variabel pengukuran dan kontrol sama dengan studi 1. Semua item dalam pengukuran masing-masing menggunakan skala Likert format lima poin (1 sangat tidak setuju hingga 5 sangat setuju). Al Cronbach untuk servant leadership, selfefficacy, dan service quality adalah 0,94, 0,73, dan 0,90.

\section{c. Pemeriksaan Asumsi Statistik, Validitas, dan Metode Umum Bias}

Pada studi 2 peneliti memeriksa asumsi statistik setelah koleksi data, termasuk normalitas, linieritas, dan multikolinearitas. Hasil pengujian tersebut menunjukkan bahwa tidak ada masalah dengan pemeriksaan asumsi statistik. Confirmatory Factor Analysis (CFA) pada penelitian ini bertujuan untuk menganalisis terhadap serangkaian hubungan secara simultan sehingga memberikan efisiensi secara statistik. Hasilnya menunjukkan kesesuaian model yang dapat diterima : X2 (df 231) 127,067, RMSEA 0,115, CFI 0,943, TLI 0,993. Semua indeks fit memenuhi Cut off Value. Oleh karena itu, semua variabel yang digunakan telah memenuhi nilai reliabilitas dan validitas konstruk.

\section{d. Analisis dan Hasil}

Seperti yang dapat dilihat pada studi 1, bahwa servant leadership berkorelasi positif terhadap service quality of employee dengan koefisien korelasi 0,374 $(p<0,01)$ dan self efficacy dengan koefisien korelasi 0,453 $(p<0,01)$. Maka, hal tersebut dapat diprediksikan bahwa servant leadership dan self efficacy cukup berkorelasi satu sama lain. Deskripsi mengenai variabel yang terkandung dalam model penelitian ini dapat dirincikan sebagai berikut :

\begin{tabular}{ll} 
Variable counts (Group number 1) & \\
Number of variables in your model: & 52 \\
\hline Number of observed variables: & 24 \\
\hline Number of unobserved variables: & 28 \\
\hline Variable counts (Group number 1) & \\
Number of exogenous variables: & 27 \\
\hline
\end{tabular}

Tabel 4. Estimasi Paramater Model 
Tabel 5. Hasil Pengujian Regresi

\begin{tabular}{l} 
Variable counts (Group number 1) \\
Number of endogenous variables: \\
Result (Default model) \\
Minimum was achieved \\
\hline Chi-square $=127,067$ \\
\hline Degrees of freedom $=231$ \\
\hline Probability level $=, 236$ \\
Sumber: Data Diolah Penulis
\end{tabular}

Pada hasil analisis model yang mengandung tiga variabel tersebut dilakukan untuk menyajikan estimasi parameter yang digunakan untuk menilai layak atau tidaknya suatu model. Oleh karena penyebaran kuesioner pada dua studi ini dilakukan sekaligus oleh peneliti, maka perhitungan mengenai estimasi parameter pada studi 1 dan studi 2 dinyatakan memiliki kesamaan dalam perhitungan, yakni pada nilai $R_{2}$ dari model 1 dan model 2 sebesar 127,067.

\section{e. Tes Hipotesis}

Peneliti menghitung dua nilai pengujian efek langsung variabel $X_{1}$ terhadap $Y$ dan pengujian efek moderasi variabel $Z$ terhadap hubungan $X_{1}$ dan $Y$. Masing-masing berdasarkan tingkat signifikansi. Tabel 3 menunjukkan rangkuman hasil pengujian regresi untuk hubungan antara servant leadership, self efficacy, dan service quality of employee.

\begin{tabular}{ll} 
Hasil Pengujian Regresi & Keterangan \\
Self effficacy berpengaruh signifikan terhadap service quality of employee & Diterima \\
\hline $\begin{array}{l}\text { Servant leadership dapat memoderasi antara Self effficacy dengan service quality of } \\
\text { employee }\end{array}$ & Diterima \\
\hline
\end{tabular}

Sumber: Data Diolah Penulis

Hipotesis 3 menyatakan bahwa servant leadership memoderasi hubungan antara self efficacy of service quality of employee dan service quality of employee. Hasil dari penelitian ini menunjukkan bahwa servant leadership antara self efficacy secara signifikan dapat memoderasi service quality of employee ASN di KKP. Hal ini terlihat dari koefisien jalur positif sebesar 0,374 dengan CR sebesar 4,216 dan diperoleh signifikasi (p) 0,000 <0,05, maka Ho ditolak dan Ha diterima, yang mengartikan bahwa servant leadership dapat memoderasi antara self efficacy terhadap service quality of employee ASN di KKP. Hasil dari pengujian moderasi servant leadership antara self efficacy dengan service quality of employee ASN di KKP diperoleh hasil 0,453 $\times 0,374=$ 0,169 atau $16,9 \%$, yang artinya peran moderasi servant leadership dapat memberikan pengaruh terhadap service quality of employee sebesar 16,9\%.

\section{Hasil Dan Pembahasan}

\section{III.a. Pengaruh Servant Leadership terhadap Service Quality of Employee}

Hasil dari pengujian pengaruh langsung servant leadership terhadap service quality of employee pada penelitian ini menunjukkan bahwa servant leadership berpengaruh signifikan terhadap service quality of employee ASN di KKP. Hal ini selaras dengan penelitian yang menunjukkan bahwa ketika individu menerima dan dipengaruhi oleh servant leadership yang baik, maka mereka sendiri akan menunjukkan reaksi positif (Brière, Le, and Olivier 2020). Brière (2020) dalam penelitiannya menjelaskan bahwa individu yang mendapatkan pendekatan servant leadership dalam organisasinya akan mampu mendorong mereka untuk menjadi pengikut yang lebih etis dan prososial, sehingga akan mendukung kualitas kerja yang baik.

Hal yang demikian pun penting bagi ASN yang bekerja di sektor publik untuk 
lebih percaya diri dengan kompetensinya dan menangani kompleksitas pekerjaan untuk terus berinovasi dalam memberikan pelayanan yang berkualitas tinggi. Dalam organisasi sektor publik, perilaku karyawan dikatakan sangat bergantung pada bagaimana kepemimpinan yang diberlakukan di dalamnya (Yuliansyah and Khan 2017). Terutama, ketika keinginan mereka untuk berpartisipasi dapat dihargai dan didorong secara objektif oleh manajemen puncak (Yuliansyah and Khan 2017). Hal ini serupa dengan pernyataan Gist and Mitchell (1992) dalam (Yuliansyah and Khan 2017) terkait service quality ASN dalam organisasi publik yang akan meningkat apabila top management mengizinkan pengikutnya untuk menyampaikan sudut pandangnya secara lisan. Sehingga, dikatakan dapat meningkatkan kinerja yang lebih baik.

Para ASN yang ada telah dapat melakukan pendekatan kepada pemimpin yang fokus utamanya dapat berinteraksi dalam bidang kerja. Pemimpin dengan karakteristik servant leadership telah menjadikan sebuah masalah yang serius dalam organisasi publik seperti Kementerian Kelautan dan Perikanan (KKP) untuk dapat terus bergerak maju dan lebih baik ke depannya. Dalam situasi seperti inilah, peran servant leadership dibutuhkan oleh para ASN yang bekerja di Kementerian Kelautan dan Perikanan (KKP). Hal tersebut didukung dengan pernyataan mengenai peran penting servant leadership dalam penelitian Schwarz et al (2020) bahwa servant leadership tidak hanya meningkatkan self-efficacy ASN, tetapi juga Public Service Motivation (PSM) yang dapat membantu menekankan pentingnya melayani masyarakat secara luas kepada ASN.

\section{III.b. Pengaruh Self Efficacy of Service Quality terhadap Service Quality of Employee}

Hasil dari pengujian pengaruh langsung self efficacy of service quality terhadap service quality of employee penelitian ini menunjukkan bahwa self efficacy berpengaruh signifikan terhadap service quality of employee ASN di KKP. ASN yang telah memiliki self-efficacy dengan tingkat tinggi telah dibuktikan akan lebih percaya diri dalam menghadapi tantangan pekerjaan dan menangani masalah dalam bekerja di kelembagaan publik KKP. Hal ini didukung dengan adanya penelitian yang mengatakan bahwa kualitas kinerja yang positif dapat memberikan feedback berupa motivasi intrinsic yang meningkat, seperti self-efficacy dan sebaliknya, apabila kualitas kinerja yang dihasilkan adalah semakin berkurang, maka self-efficacy karyawan pun juga akan berkurang (Jacobsen and Andersen 2016).

Pada kemampuannya dalam melayani pelanggan, ASN seringkali dipengaruhi oleh faktor psikologis yaitu kompetensi yang dimiliki telah menjadi lebih baik dan kemungkinan dari berbagai macam faktor internal maupun eksternal yang ada di Kementerian Kelautan dan Perikanan (KKP). Faktor internal organisasi meliputi pemimpin organisasi. Ketika individu menerima dan dipengaruhi oleh servant leadership yang baik, maka mereka sendiri akan menunjukkan reaksi positif dan membalas kebaikan yang mereka terima dari servant leadership bagi para pemangku kepentingan internal dan menghasilkan layanan dengan kualitas tinggi kepada seluruh masyarakat yang ingin dilayani dengan baik di Kementerian Kelautan dan Perikanan (KKP). Hal inilah yang kemudian menjadikan self-efficacy sebagai salah satu penentu kinerja organisasi. Semakin tinggi self-efficacy karyawan, maka karyawan akan mampu mengatur dan melaksanakan tugas sesuai dengan potensi yang berkualitas yang dapat mereka rasakan (Jacobsen and Andersen 2016).

\section{III.c. Servant Leadership Memoderasi Hubungan antara Self Efficacy of Service Quality dan Service Quality Of Employee}

Hasil dari pengujian moderasi pada hubungan antara self efficacy of service quality dan service quality of employee penelitian ini menunjukkan bahwa servant leadership antara self efficacy secara signifikan dapat memoderasi service quality of employee ASN di KKP. Selain itu, hasil pengujian moderasi pada hubungan kedua variabel tersebut menunjukkan bahwa service quality of employee akan lebih tinggi ketika keduanya (self efficacy dan servant leadership) meningkat.

Kemampuan seorang pemimpin dalam memengaruhi orang lain umumnya dilakukan dengan memberikan motivasi untuk bekerja sesuai dengan tujuan dan 
sasaran yang berlaku dalam organisasi, seperti di Kementerian Kelautan dan Perikanan (KKP). Secara umum, seorang pemimpin yang baik akan memberlakukan gaya kepemimpinan yang dapat memengaruhi bagaimana perilaku ASN tersebut bekerja untuk sampai menuju ke arah yang lebih baik atau tujuan-tujuan yang sudah dibuat oleh pimpinan dalam organisasi publik di KKP (Eva et al. 2019).

Selain memberikan pengaruh terhadap bagaimana perilaku ASN tersebut, pimpinan dengan pendekatan servant leadership akan dapat menguasai banyak hal, seperti manajemen yang dibutuhkan untuk mengatasi masalah (misalnya, membuat tata tertib, menyusun rencana-rencana formal, dan merancang struktur organisasi yang ketat) (Wang, Xu, and Liu 2018). Selain itu, melakukan pemantauan terhadap hasil yang sudah dilakukan dengan cara membandingkan rencana yang telah ditetapkan sebelumnya dalam lingkup Kementerian Kelautan dan Perikanan (KKP) dengan implementasinya saat bekerja. Dalam penelitian sebelumnya, peran pemimpin yang demikian akan mampu mengubah karyawan menjadi kunci keberhasilan organisasi, misalnya saling bertukar informasi, dan untuk mendapatkan dukungan eksternal (Stollberger et al. 2019).

\section{Kesimpulan}

Dalam mengajukan hipotesis penelitian ini, peneliti melakukan dua studi. Studi 1 menggunakan analisis hubungan langsung antar variabel, sedangkan dalam studi 2 menggunakan efek moderasi servant leadership. Kedua studi ini meggunakan sampel yang sama, yaitu ASN di Kementerian Kelautan dan Perikanan. Kedua studi ini menghasilkan hasil yang serupa. Dalam setiap studi, service quality of employee akan meningkat ketika servant leadership dan self efficacy yang dirasakan oleh ASN juga tinggi. Moderasi dari servant leadership membangun hubungan antara self efficacy dan service quality, dan terkait tingginya tingkat self efficacy terhadap service quality of employee ditunjukkan dengan keadaan servant leadership yang dirasakan oleh ASN berada pada tingkat yang tinggi.

Pada sejumlah ASN di KKP dalam berbagai unit/divisi kerja dengan tingkat servant leadership yang tinggi dan rendah akan mewakili seberapa besar peningkatan self efficacy para ASN, khususnya dalam hal memberikan pelayanan pada masyarakat. Hal ini tentu berkaitan dengan service quality of employee. Sebagian pengaruh yang diberikan oleh servant leadership akan berdampak pada bagaimana ASN dapat terinspirasi oleh kemampuan pemimpin secara konseptual yang akan berkontribusi dalam memberikan dorongan kinerja terbaik para ASN (Chiniara and Bentein 2018). Hal ini penting untuk diteliti karena literature sebelumnya belum secara eksplisit mengungkapkan terkait moderasi yang dihasilkan oleh servant leadership. Meskipun banyak kemajuan mengenai penelitian dengan tema ini, namun sebagian besar peneliti terdahulu masih berfokus pada ciri-ciri psikologis seperti collectivism, trust, dan love (Udayar et al. 2020).

Penelitian ini memiliki beberapa kontribusi secara praktis dan akademi. Pertama, bagi perusahaan/organisasi publik, studi ini secara praktis ingin menegaskan kembali peran penting dari servant leadership dalam hal pembentukan service quality of employee di sektor publik. Hasil penelitian ini dapat dijadikan sebagai bahan perencanaan dan pertimbangan organisasi publik dalam meningkatkan kualitas pelayanan ASN, rasa percaya diri, dan kepemimpinan yang mampu mengayomi individu/pengikutnya dengan baik. Kedua, bagi peneliti di masa depan, hasil penelitian pada studi ini dapat dijadikan sebagai bahan informasi dan masukan terhadap peneliti selanjutnya yang ingin meneliti di bidang yang sama.

Kontribusi penelitian secara teoritis pada studi ini diharapkan mempunyai manfaat bagi pengembangan ilmu manajemen sumber daya manusia. Khususnya tentang service quality of employee, self-efficacy, dan servant leadership.

Seperti penelitian lain, penelitian ini juga memiliki keterbatasan. Pertama, peneliti tidak menguji efek moderasi dari self efficacy antara servant leadership dengan service quality of employee. Studi di masa depan dapat melakukannya jika penelitian ini didukung dengan berbagai dasar teoritis yang logis. Kedua, sampel yang digunakan 
peneliti adalah para ASN di Kementerian Kelautan dan Perikanan dilakukan secara online sehingga data yang diperoleh dipersatukan pada KKP sejumlah 222 data kuesioner yang berhasil diisi. Oleh karena penelitian ini dilakukan dengan sampel dan jumlah yang sama. Peneliti di masa depan dapat mempertimbangkan kembali untuk dapat menggunakan sampel dan jumlah yang berbeda pada masing-masing studi.

\section{Ucapan Terima Kasih}

Penulis mengucapkan terima kasih kepada semua pihak yang turut terlibat dalam proses penelitian ini khususnya para ASN KKP serta para dosen Program Studi Magister Sains Manajemen Universitas Airlangga yang telah memberikan dukungan dan bimbingan dalam pengerjaan penelitian ini.

\section{Daftar Referensi}

Andre, and Donald Crestofel Lantu. (2015). "Servant Leadership and Human Capital Management: Case Study in Citibank Indonesia." Procedia - Social and Behavioral Sciences. https://doi.org/10.1016/j. sbspro.2015.01.314.

Berry, Theron R. (2015). “Servant-Leadership as an Institutionalized Model in Air Force Education.” Journal of Education and Human Development 4 (2): 123-29. https://doi.org/10.15640/jehd.v4n2a14.

Boukis, Achilleas, Christos Koritos, Kate L. Daunt, and Avraam Papastathopoulos. (2020). "Effects of Customer Incivility on Frontline Employees and the Moderating Role of Supervisor Leadership Style." Tourism Management. https://doi.org/10.1016/j.tourman.2019.103997.

Brender-Ilan, Yael, and Zachary Sheaffer. (2019). "How Do Self-Efficacy, Narcissism and Autonomy Mediate the Link between Destructive Leadership and Counterproductive Work Behaviour." Asia Pacific Management Review. https://doi.org/10.1016/j.apmrv.2018.05.003.

Brière, Mathilde, Jeanne Le, and Roy Olivier. (2020). "Linking Servant Leadership to Positive Deviant Behavior: The Mediating Role of Self-Determination Theory," no. June: 1-14. https://doi.org/10.1111/ jasp.12716.

“Can Public Leadership Increase Public Service Motivation and Job Performance?” (2020). 9999: 1-12. https://doi.org/10.1111/puar.13182.

Chiniara, Myriam, and Kathleen Bentein. (2018). “The Servant Leadership Advantage: When Perceiving Low Differentiation in Leader-Member Relationship Quality Influences Team Cohesion, Team Task Performance and Service OCB.” Leadership Quarterly. https://doi.org/10.1016/j.Leaqua.2017.05.002.

Demircioglu, Mehmet Akif, and David B. Audretsch. (2017). "Conditions for Innovation in Public Sector Organizations.” Research Policy 46 (9): 1681-91. https://doi.org/10.1016/j.respol.2017.08.004.

Dhar, Rajib Lochan. (2015). "Service Quality and the Training of Employees: The Mediating Role of Organizational Commitment." Tourism Management 46: 419-30. https://doi.org/10.1016/j. tourman.2014.08.001.

Eva, Nathan, Mulyadi Robin, Sen Sendjaya, Dirk van Dierendonck, and Robert C. Liden. (2019). "Servant Leadership: A Systematic Review and Call for Future Research.” Leadership Quarterly 30 (1): 111-32. https://doi.org/10.1016/j.leaqua.2018.07.004.

Harwiki, Wiwiek. (2016). "The Impact of Servant Leadership on Organization Culture, Organizational Commitment, Organizational Citizenship Behaviour (OCB) and Employee Performance in Women Cooperatives." Procedia - Social and Behavioral Sciences. https://doi.org/10.1016/j.sbspro.2016.04.032.

Ismayilova, Khayala, and Robert M. Klassen. (2019). "Research and Teaching Self-Efficacy of University Faculty: Relations with Job Satisfaction.” International Journal of Educational Research. https://doi. org/10.1016/j.ijer.2019.08.012.

Jacobs, Gilbert. (2006). "Servant Leadership and Follower Commitment." Servant Leadership Research Roundtable. https://regentparents.regent.edu/wp-content/uploads/2020/12/jacobs.pdf

Jacobsen, Christian Bøtcher, and Lotte Bøgh Andersen. (2016). "Leading Public Service Organizations : How to Obtain High Employee Self-Efficacy and Organizational Performance” 9037 (May). https://doi.org/10 .1080/14719037.2016.1153705.

Koyuncu, Mustafa, Ronald J Burke, Marina Astakhova, Duygu Eren, and Hayrullah Cetin. (2014). "Servant Leadershio and Perceptions of Service Quality Provided by Front-Line Service Workers in Hotels in Turkey." International Journal of Contemporary Hospitality Management. https://www.econbiz.de/ Record/servant-leadership-and-perceptions-service-quality-provided-front-line-service-workershotels-turkey-achieving-competitive-advantage-koyuncu-mustafa/10010426072

Kurniawan, Moh Heri, Rr Tutik Sri Hariyati, and Efy Afifah. (2019). "The Relationship between Caring Preceptor, Self-Efficacy, Job Satisfaction, and New Nurse Performance.” Enfermeria Clinica. https://doi. org/10.1016/j.enfcli.2019.04.069.

Luu, Tuan Trong. (2020). “Linking Authentic Leadership to Salespeople's Service Performance: The Roles of Job Crafting and Human Resource Flexibility.” Industrial Marketing Management. https://doi. org/10.1016/j.indmarman.2019.06.002.

Morales, Francisco M., and José M. Pérez-Mármol. (2019). "The Role of Anxiety, Coping Strategies and Emotional Intelligence on General Perceived Self-Efficacy in University Students." Frontiers in Psychology 10 (JULY). https://doi.org/10.3389/fpsyg.2019.01689.

Niu, Han Jen. (2010). "Investigating the Effects of Self-Efficacy on Foodservice Industry Employees' Career Commitment." International Journal of Hospitality Management. https://doi.org/10.1016/j. 
ijhm.2010.03.006.

Pete Devon, Erin, Rebecca Tenney-Soeiro, Jeanine Ronan, and Dorene F. Balmer. (2019). "A Pediatric Preintern Boot Camp: Program Development and Evaluation Informed by a Conceptual Framework." Academic Pediatrics 19 (2): 165-69. https://doi.org/10.1016/j.acap.2018.08.006.

Qiu, Shaoping, Larry M. Dooley, and Lei Xie. (2020). "How Servant Leadership and Self-Efficacy Interact to Affect Service Quality in the Hospitality Industry: A Polynomial Regression with Response Surface Analysis." Tourism Management. https://doi.org/10.1016/.tourman.2019.104051.

Rachmawati, Ani Wahyu, and Donald C. Lantu. (2014). "Servant Leadership Theory Development \& Measurement." Procedia-Socialand BehavioralSciences. https://doi.org/10.1016/j.sbspro.2014.02.445.

Sataloff, Robert T, Michael M Johns, and Karen M Kost. n.d. “No 主観的健康感を中心とした在宅高齢者におけ る健康関連指標に関する共分散構造分析Title,” no. 1995.

Stollberger, Jakob, Mireia Las Heras, Yasin Rofcanin, and Maria José Bosch. (2019). "Serving Followers and Family? A Trickle-down Model of How Servant Leadership Shapes Employee Work Performance." Journal of Vocational Behavior. https://doi.org/10.1016/j.jvb.2019.02.003.

Sun, Anna, and Jiangang Xia. (2018). "Teacher-Perceived Distributed Leadership, Teacher Self-Efficacy and Job Satisfaction: A Multilevel SEM Approach Using the 2013 TALIS Data." International Journal of Educational Research 92 (September): 86-97. https://doi.org/10.1016/j.ijer.2018.09.006.

Tabatabaei, Shahnaz, Neda Jashani, Meisam Mataji, and Niloofar Amir Afsar. (2013). "Enhancing Staff Health and Job Performance through Emotional Intelligence and Self-Efficacy." Procedia - Social and Behavioral Sciences. https://doi.org/10.1016/j.sbspro.2013.07.011.

Udayar, Shagini, Nimrod Levin, Yuliya Lipshits-Braziler, Shékina Rochat, Annamaria Di Fabio, Itamar Gati, Laurent Sovet, and Jérôme Rossier. (2020). "Difficulties in Career Decision Making and Self-Evaluations: A Meta-Analysis." Journal of Career Assessment 28 (4): 608-35. https://doi. org/10.1177/1069072720910089.

Wang, Zhen, Haoying Xu, and Yukun Liu. (2018). "Servant Leadership as a Driver of Employee Service Performance: Test of a Trickle-down Model and Its Boundary Conditions." Human Relations. https://doi. org/10.1177/0018726717738320.

Yin, Hongbiao, Jiying Han, and Brian E. Perron. (2020). "Why Are Chinese University Teachers (Not) Confident in Their Competence to Teach? The Relationships between Faculty-Perceived Stress and Self-Efficacy." International Journal of Educational Research. https://doi.org/10.1016/j.ijer.2019.101529.

Yuliansyah, Yuliansyah, and Ashfaq Ahmad Khan. (2017). "International Review of Public Administration A Revisit of the Participative Budgeting and Employees ' Self-Efficacy Interrelationship - Empirical Evidence from Indonesia 's Public Sector." International Review of Public Administration 4659 (June): 1-18. https://doi.org/10.1080/12294659.2017.1325584. 